\title{
ANALISA KECENDRUNGAN MASYARAKAT TERHADAP TRANSPORTASI UDARA MENGGUNAKAN METODE AHP PADA PT.BULANG PERSADA TOUR DAN TRAVELKOTA
}

\author{
Dinda Permata Sari ${ }^{1)}$, Asnawati ${ }^{2)}$, Leni Natalia Zulita ${ }^{3)}$ \\ ${ }^{1,2,3)}$ Program Studi Sistem Informasi Fakultas IImu Komputer Universitas \\ Dehasen Bengkulu
}

Email: sopian21@gmail.com

\begin{abstract}
How to Cite :
Dinda Permatasari, Asnawati, Leni Natalia zulita. 2020. Analisa Kecendrungan Masyarakat Terhadap Transportasi udara Menggunakan Metode AHP PAD APT. Bulan Persada Tour Dan Travel Kota. Gatotkaca Journal. DOI:https://Doi.Org/10.37638/Gatotkaca.1.2. 214-227
\end{abstract}

\section{ARTICLE HISTORY}

Received [8 Oktober 2020]

Revised [16 November 2020]

Accepted [30 Desember 2020]

\section{KEYWORDS}

AHP Method, Air Transportation, Visual Basic 6.0

This is an open access article under the $C C-B Y-S A$ license

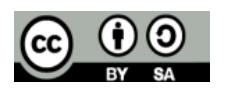

\begin{abstract}
ABSTRAK
Komputer sangat dibutuhkan oleh banyak perusahaan swasta maupun pemerintahan, dengan berbagai macam kebutuhan. Salah satu Angkasa Pura, Salah satu jenis transportasi yang sangat dibutuhkan oleh manusia dalam pemenuhan kebutuhannya adalah transportasi udara yang ada pada angkasa pura wilayah Bengkulu sebagai system penunjuk arah Pelayanan. Sistem Aplikasi kecendrungan masyarakat terhadap transportasi udara menggunakan Metode AHP Menggunakan Visual Basic 6.0.dalam melakukan penyebaran akses informasi dan komunikasi belum secara khusus menggunakan aplikasi untuk memudahkannya. Sedangkan informasi yang disampaikan masih menggunakan dan selebaran atau kotak saran pada bandara fatmawati sehingga informasi yang ditampung tidak akurat. Sistem Aplikasi kecendrungan masyarakat terhadap transportasi udara menggunakan Metode AHP Menggunakan Visual Basic dapat menjadi masukan kepada pihak maskapai sehingga menjadi bandara bertaraf internasional.
\end{abstract}

\section{ABSTRACT}

Computers are needed by many private and government companies, with a variety of needs. One of Angkasa Pura, one type of transportation that is needed by humans in fulfilling their needs is air transportation that exists in the temple space of the Bengkulu region as a system of directing services.The application system of the public tendency towards air transportation uses the AHP Method Using Visual Basic 6.0. in disseminating information and communication access, it has not specifically used the application to facilitate it. While the information submitted is still using the leaflet or 


\section{EAATOT RACA}

suggestion box at Fatmawati airport so that the information collected is not accurate. The application system of the public tendency towards air transportation using the AHP Method Using Visual Basic can be an input to the airline so that it becomes an international airport.

\section{PENDAHULUAN}

Komputer sangat dibutuhkan oleh banyak perusahaan swasta maupun pemerintahan, dengan berbagai macam kebutuhan.Salah satu Angkasa Pura, Salah satu jenis transportasi yang sangat dibutuhkan oleh manusia dalam pemenuhan kebutuhannya adalah transportasi udara yang ada pada angkasa pura wilayah Bengkulu sebagai system penunjuk arah Pelayanan.

Perkembangan jumlah perusahaan penerbangan di satu sisi menguntungkan bagi para pengguna jasa transporatsi udara (penumpang dan pemilik kargo) karena akan banyak pilihan. Perusahaan-perusahaan tersebut bersaing untuk untuk menarik penumpang sebanyak-banyaknya dengan menawarkan tarif yang lebih murah atau menawarkan berbagai bonus. Namun di sisi lain, dengan tarif yang murah tersebut sering menurunkan kualitas pelayanan (service), bahkan yang lebih mengkhawatirkan lagi adalah akan menyebabkan berkurangnya kualitas pemeliharaan (maintenance) Pelayanan sehingga rawan terhadap keselamatan penerbangan dan akan berdampak kurang baik terhadap keamanan, kenyamanan dan perlindungan konsumen.

Penyediaan fasilitas dan pemberian jasa pelayanan pada setiap pengguna terminal bandar udara merupakan produk yang dihasilkan untuk dijual kepada konsumen penggua jasa dan layanan tersebut yang akan mengakibatkan adanya timbal balik yang berdampak pada penerimaan atau atau pendapatan bandar udara. Pendapatan bandar udara sendiri dipengaruhi oleh pasang surut kegiatan ekonomi dunia.Hal itu mengacu pada kemampuan konsumen dalam memberikan andil pada pendapatan bandar udara melelui penggunaan jasa layanan angkutan udara khususnya bandara Fatmawati.

Dari analisa diatas maka ditarik kesimpulan bagaimana respont masyarakat terhadap trasnportasi udara, baik dari segi kenyamanan, ketepatan waktu dan efisiensi sehingga masyarakat dapat memilih bagaimana yang terbaik menentukan maskapai yang akan diinginkan sehingga kami dari pihak Tour Bulang Persada menawarkan dengan kelebihan dan kekurangan masing-masing maskapai demi kenyamanan penumpang.

\section{LANDASAN TEORI}

\section{A. Sistem Informasi}

Sistem informasi adalah suatu sistem terintegrasi yang mampu menyediakan informasi yang bermanfaat bagi penggunanya, Menurut Leitch Rossesdalam Jogiyanto (2005:11) mengemukakan sistem informasi adalah suatu sistem didalam organisasi yang mempertemukan kebutuhan pengelolah transaksi harian, mendukung operasi, bersifat manajerial dan kegiatan strategi dari suatu organisasi dan menyediakan pihak luar tertentu dengan laporan-laporan yang diperlukan. 


\section{B. Metode AHP}

Pengambilan keputusan sudah menjadi bagian dalam kehidupan, kadangkala kita diperhadapkan pada dua atau lebih pilihan, atau pilihan mudah hingga yang paling sulit. Pada pengambilan keputusan yang melibatkan susutu sistem (sederhana atau kompleks) atau keputusan yang sifatya menentukan perjalanan perusahaan/organisasi bahkan negara maka keputusan tentu akan sulit jika hanya mengandalkan intuisi, sehingga pengambilan keputusan dilakukan setelah suatu melalui proses tertentu.

\section{Konsep Perancangan Database}

Database adalah himpunan kelompok data yang saling berhubungan yang di organisasi sedemikian rupa agar kelak dapat dimanfaatkan kembali dengan cepat dan mudah (Fathansyah, 2007:25)

\section{Bahasa Pemrograman Visual Basic}

Visual Basic merupakan salah satu bahasa pemrograman komputer yang menyediakan sarana (tool) untuk menghasilkan program-program aplikasi berbasiskan Windows.

\section{METODE PENELITIAN}

Metode yang digunakan dalam penelitian ini menggunakan metode pengembangan sistem, dimana metode penelitian ini membuat sistem informasi pembuatan pada PT. Bulang Persada, dalam merancang dan membuat sistem ini menggunakan Website dengan menganalisa kebutuhan data, tahapan implmentasi sistem menggunakan database Mysql serta melanjutkan tahapan pengujian sistem.

\section{HASILDAN PEMBAHASAN}

Penyediaan fasilitas dan pemberian jasa pelayanan pada setiap pengguna terminal bandar udara merupakan produk yang dihasilkan untuk dijual kepada konsumen penggua jasa dan layanan tersebut yang akan mengakibatkan adanya timbal balik yang berdampak pada penerimaan atau atau pendapatan bandar udara. Pendapatan bandar udara sendiri dipengaruhi oleh pasang surut kegiatan ekonomi dunia. Hal itu mengacu pada kemampuan konsumen dalam memberikan andil pada pendapatan bandar udara melelui penggunaan jasa layanan angkutan udara khususnya bandara Fatmawati bagaimana respont masyarakat terhadap trasnportasi udara, baik dari segi kenyamanan, ketepatan waktu dan efisiensi sehingga masyarakat dapat memilih bagaimana yang terbaik menentukan maskapai yang akan diinginkan sehingga kami dari pihak Tour Bulang Persada menawarkan dengan kelebihan dan kekurangan masing-masing maskapai demi kenyamanan penumpang.

\section{A. Tampilan Program}

Menu Utama terdiri dari input data, proses, output atau keluaran berupat repot cetakan dan keluar dari program untuk masuk ke system menu utama, untuk memulai program yang ada pada Sistem Aplikasi Kinerja PNS Kelurahan Jitra Dengan Menggunakan Visual Basic 6.0. Halaman menu utama merupakan suatu halaman yang menampilkan secara keseluruhan dari Aplikasi kecendrungan masyarakat terhadap transportasi udara menggunakan Metode AHP Menggunakan Visual Basic yang telah dibuat. Tampilan menu utama seperti terlihat pada gambar di bawah ini : 


\section{CATHOT [R/ACA गOURNALL}

Jumal Keilmuan Teknik: Aplikasi, Perencanaan, Rancang Bangun, Sistem, Simulasi, \& Rekayas

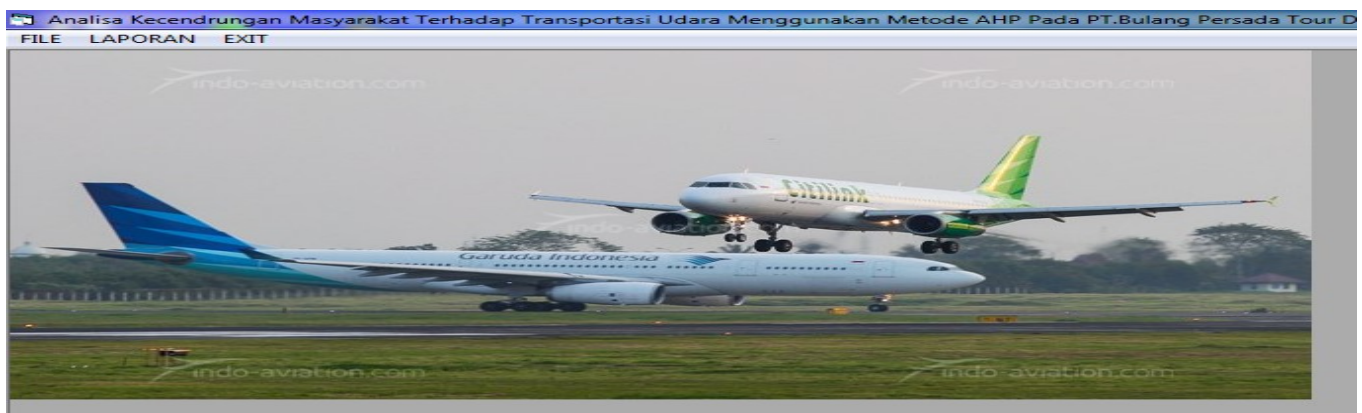

Gambar 1 Tampilan Menu Utama

Pada gambar 1 diatas merupakan halaman Menu Utama Sistem Informasi yang telah selesai dibuat. Tampilan menu utama pada Sistem Informasi ini dapat menyajikan input data dan laporan

a. Tampilan Sub Menu File

Menu ini merupakan menu yang penting, dimana pada sub menu file ini terdapat subsub menu yang digunakan untuk mengentrikan data yang berhubungan dengan system menu utama, untuk memulai program yang ada pada Sistem Aplikasi kecendrungan masyarakat terhadap transportasi udara menggunakan Metode AHP Menggunakan Visual Basic.

b. Tampilan Matrix Perbandingan Kreteria

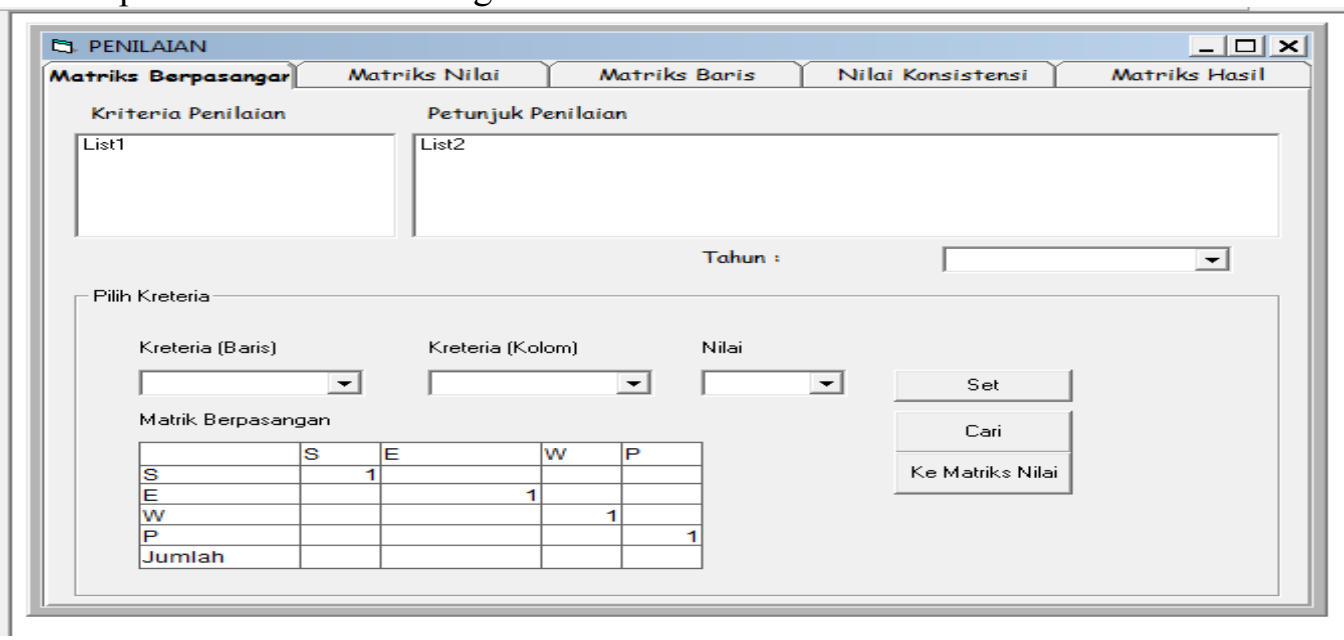

\section{Gambar 2. Matrix perbandingan}

Input data id pesawat dan nama pesawat, dan masalah sefty, ekonomi, waktu, pelayanan, kenyamanan dan jumlah, dan terdiri dari tombol tambah untuk menambahkan data, tombol koreksi untuk mengoreksi data, tombol hapus untuk menghapus data yang ada pada program dan tombol keluar untuk keluar dari program pada Sistem Aplikasi kecendrungan masyarakat terhadap transportasi udara menggunakan Metode AHP Menggunakan Visual Basic.

c. Tampilan matrix nilai kreteria 


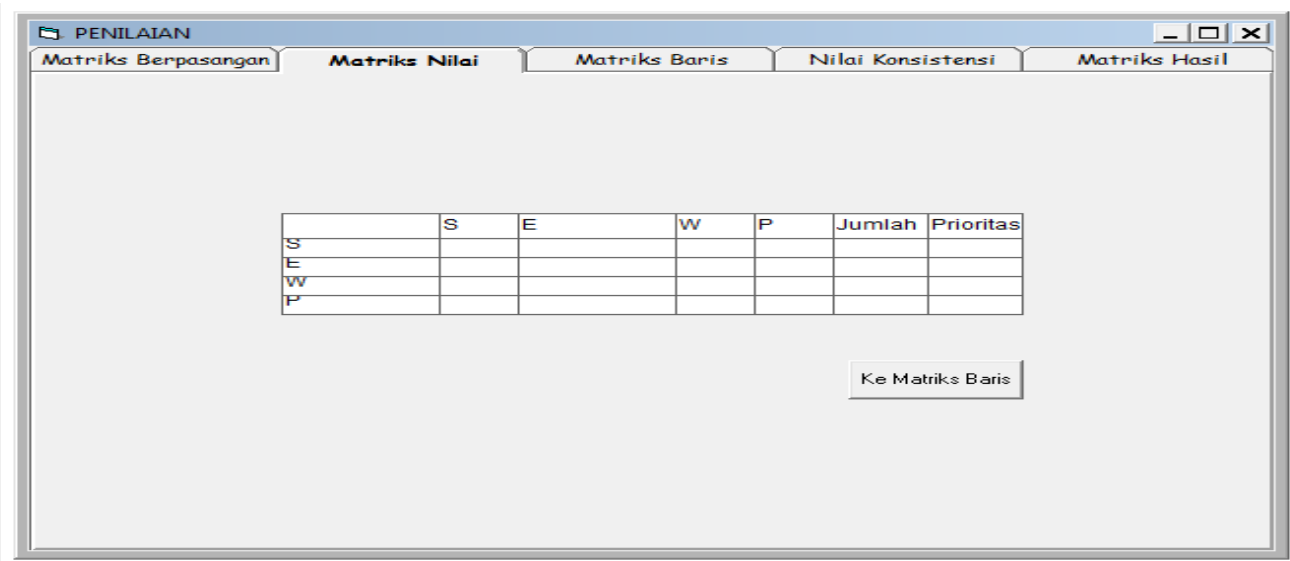

\section{Gambar 3, Tampilan nilai kreteria}

Input data kejadian teridiri dari kode Inventaris, dan terdiri dari tombol tambah untk menambahkan data, tombol koreksi untuk mengoreksi data, tombol hapus untuk menghapus data yang ada pada program dan tombol keluar untuk keluar dari program pada Sistem Aplikasi kecendrungan masyarakat terhadap transportasi udara menggunakan Metode AHP Menggunakan Visual Basic.

d. Tampilan Matrix nilai Baris

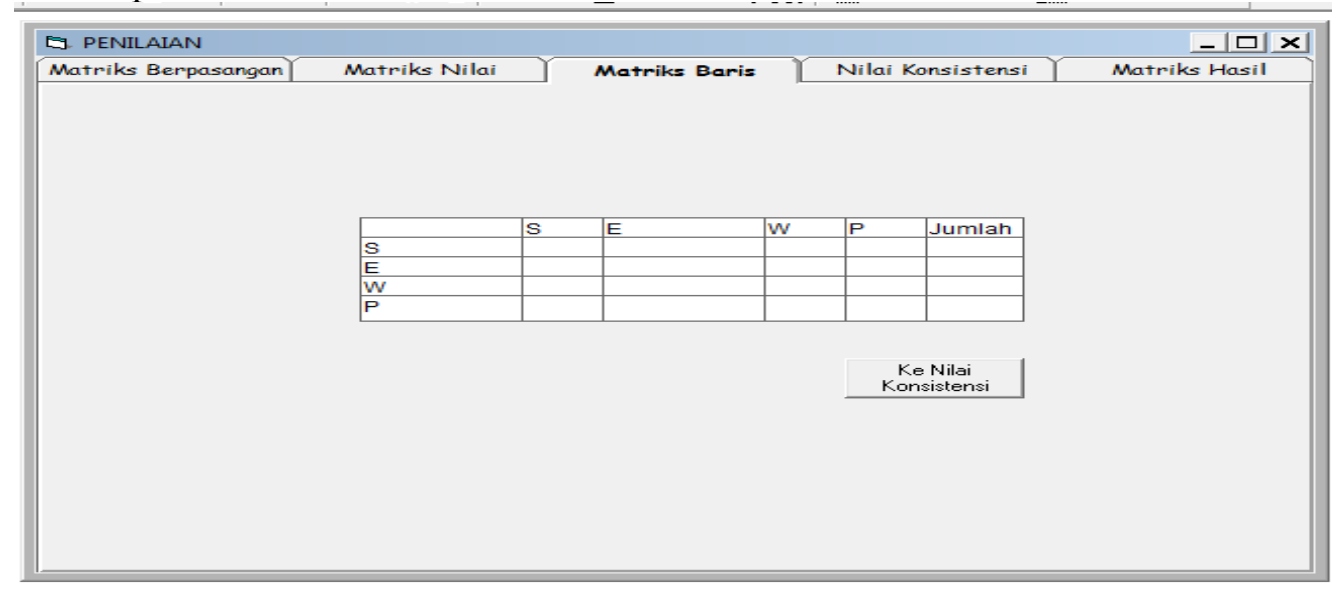

\section{Gambar 4. Tampilan matrix nilai barisan}

Input data kejadian teridiri dari kode Inventaris, dan terdiri dari tombol tambah untk menambahkan data, tombol koreksi untuk mengoreksi data, tombol hapus untuk menghapus data yang ada pada program dan tombol keluar untuk keluar dari program pada Sistem Aplikasi kecendrungan masyarakat terhadap transportasi udara menggunakan Metode AHP Menggunakan Visual Basic.

e. Tampilan Matrix konsistensi 


\section{CAAOT RAGA JOURNAL}

Jurnal Keilmuan Teknik: Aplikasi, Perencanaan, Rancang Bangun, Sistem, Simulasi, \& Rekaya:

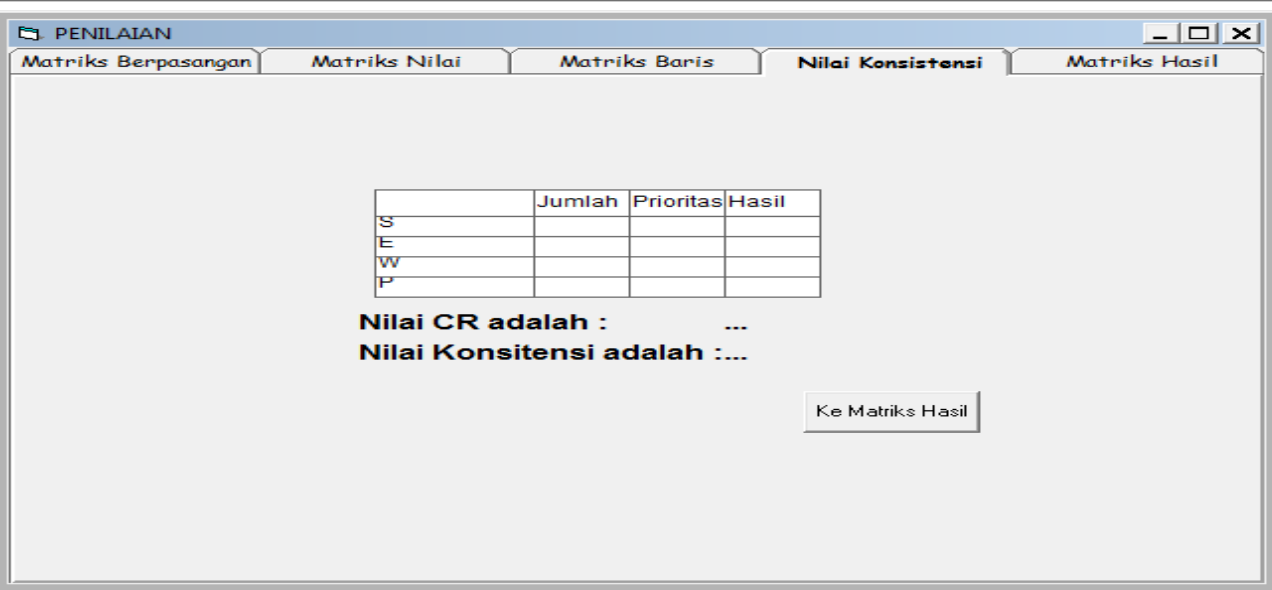

Dari hasil nilai konsistensi tabel diatas didapat dari matriks baris sehingga nilai dari perhitungan metode akan menampilkan nilai CR dan nilai konsistensi.

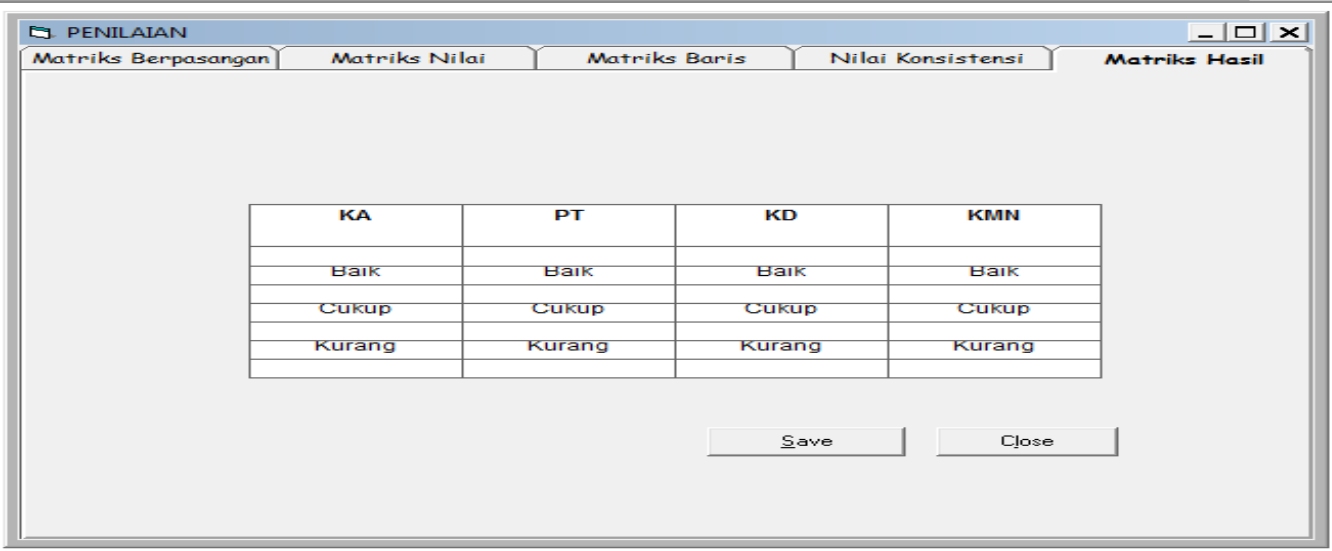

\section{Gambar 5. Tampilan matrix konsistensi}

Input id pesawat, nama pesawat, safty, ekonomi, waktu dan pelayanan, dan terdiri dari tombol tambah untk menambahkan data, tombol koreksi untuk mengoreksi data, tombol hapus untuk menghapus data yang ada pada program dan tombol keluar untuk keluar dari program pada Sistem Aplikasi kecendrungan masyarakat terhadap transportasi udara menggunakan Metode AHP Menggunakan Visual Basic.

\section{B. Tampilan output}

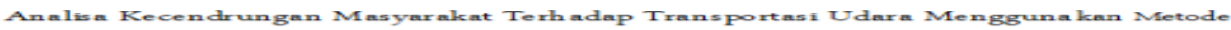
AFP Pada PT. Bulang Persade Tour dan Travel Kota Bengloulu.

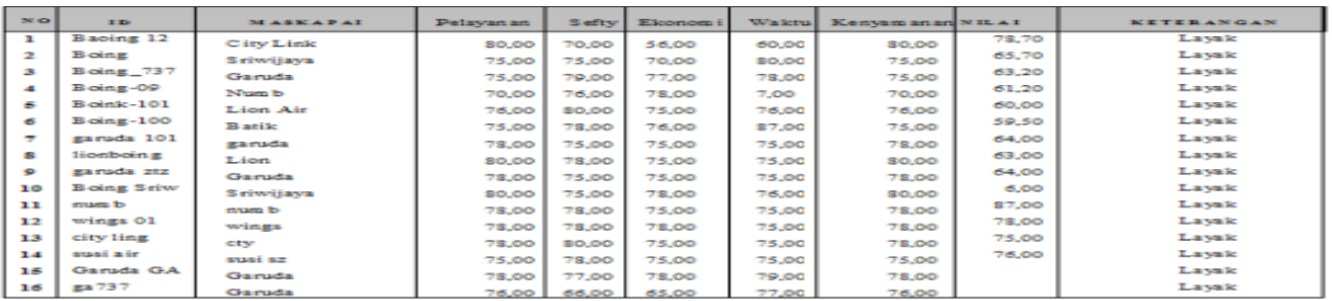




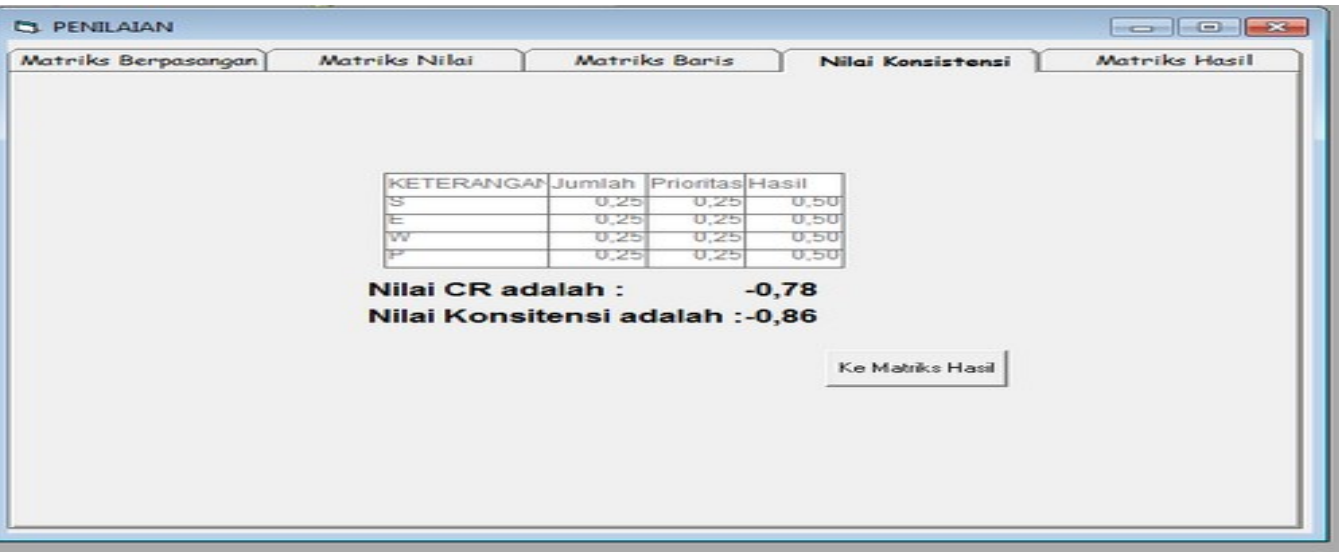

Dari hasil diatas dapat disimpulkan dengan 5 kreteria yang terdiri dari Pelayanan, Safty, Ekonomi, Waktu, kenyamanan didapat dengan nilai akhir ada la tipe pesawat City Link dengan nilai akhir 78,00 \% dengan nilai CR 0,78 dan konstanta, 0.86 , sehingga dari hasil metode AHP dapat disimpulkan maskapai city link dengan 5 kreteria memenuhi kebutuhan masyarakat kota bengkulu.

Memperoleh nilai selisih hasil normallisasi yang bernilai 0 , artinya proses iterasi tidak perlu lagi dilanjutkan. Karena proses iterasi berhenti pada iterasi 4, maka nilai pembobotan yang digunakan adalah nilai normalisasi hasil iterasi ke-4, sehingga, sekarang tiap-tiap elemen penyusun kriteria dapat di susun sebagai berikut:

1. Pelayanan rata-rata kepuasan masyarakat 80

2. Sefty rata-rata kepuasan masyarakat 70

3. Ekonomi rata-rata kepuasan masyarakat 75

4. Waktu rata-rata kepuasan masyarakat 75

5. Kenyamanan rata-rata kepuasan masyarakat 78

Terhadap pelayanan City Link dengan jadwal penerbangan yang nyaman tidak mengalami keterlambatan dengan akurasi CR 0.78 .

\section{Dari hasil pengujian di PT Bulang}

Pada PT.Bulang persada ketika diuji sampel dengan menggunakan metode AHP dan melihat kecendrungan masyarakat terhadap transportasi udara menggunakan metode.

\begin{tabular}{|c|l|c|c|c|c|}
\hline No & \multicolumn{1}{|c|}{ Pax name } & Crr & T.pax & Booking & Route \\
\hline 1 & Bimo raharjo & JT & 1 & XJGGRZ & BKS-TKG \\
\hline 2 & Rony Roosady & JT & 1 & XJGGRZ & BKS-TKG \\
\hline 3 & Arief budiman & JT & 1 & OGJEGO & BKS-TKG \\
\hline 4 & Septy miniarni & JT & 1 & OGJEGO & BKS-TKG \\
\hline 5 & Jarot affandi & JT & 1 & XLXSTP & BKS-TKG \\
\hline 6 & Sujoko primono & JT & 1 & XLXSTP & BKS-TKG \\
\hline 7 & Maulya elsyahnty & JT & 2 & HGYAYV & DJB-BKS \\
\hline 8 & Drh majestika & JT & 1 & QJCJKD & BKS-CGK \\
\hline 9 & Drh majestika & JT & 1 & XESJNV & CGK-BKS \\
\hline 10 & Dika jaya & JT & 1 & XSHRME & DJB-BKS \\
\hline 11 & Dika jaya & JT & 1 & CLSQFK & BKS-PLM \\
\hline 12 & Maulya elsyahnty & JT & 1 & CLSQFK & BKS-PLM \\
\hline 13 & Chintya Dewi & GA & 1 & SY53WI & BKS-CGK \\
\hline 14 & Nobela sari & GA & 1 & MOSJND & UPG-CGK \\
\hline
\end{tabular}




\section{EATOT RAC/A}

Jurnal Keilmuan Teknik: Aplikasi, Perencanaan, Rancang Bangun, Sistem, Simulasi, \& Rekaya:

\begin{tabular}{|c|c|c|c|c|c|}
\hline 15 & Selvianita pramesti & GA & 1 & MOPXJ3 & UPG-CGK \\
\hline 16 & Azzahra salsabila & GA & 1 & MOGVOL & UPG-CGK \\
\hline 17 & Aryantito akbar & GA & 1 & MIV9WC & UPG-CGK \\
\hline 18 & Ade tri anggreini & GA & 1 & MK3LUU & UPG-CGK \\
\hline 19 & Devie purnama ningsi & GA & 1 & MMSTM3 & UPG-CGK \\
\hline 20 & Dufferez putra D & GA & 1 & MN5HVZ & UPG-CGK \\
\hline 21 & Chintya Dewi & GA & 1 & MNRL5M & UPG-CGK \\
\hline 22 & Tiara hunnun $\mathrm{E}$ & GA & 1 & MTZJAP & UPG-CGK \\
\hline 23 & Annisa rahma $\mathrm{J}$ & GA & 1 & MUBWGE & UPG-CGK \\
\hline 24 & Salju qurrata A & GA & 1 & MU8JEH & UPG-CGK \\
\hline 25 & Emagina rahmanita & GA & 1 & MUID98 & UPG-CGK \\
\hline 26 & Risky pritasari & GA & 1 & MTZXV9 & UPG-CGK \\
\hline 27 & Mulya sarti apriani & GA & 1 & MTPOGM & UPG-CGK \\
\hline 28 & Reko muhardi & GA & 1 & MTPF2A & UPG-CGK \\
\hline 29 & Feni putri anjani & GA & 1 & MP8W3B & UPG-CGK \\
\hline 30 & Ardi Muhaimin & GA & 1 & MPBEKV & UPG-CGK \\
\hline 31 & Yuike desri yanti & GA & 1 & MO6USU & UPG-CGK \\
\hline 32 & Nur aulia siswisiarni & GA & 1 & MTZ4NM & UPG-CGK \\
\hline 33 & Ibrahim & GA & 1 & NET26S & UPG-CGK \\
\hline 34 & Ari nurdiana & GA & 1 & NDITIJ & UPG-CGK \\
\hline 35 & Eva nopianti & GA & 1 & NEFKJ7 & UPG-CGK \\
\hline 36 & Erika kurniat & GA & 1 & NE5H7X & UPG-CGK \\
\hline 37 & Andika & GA & 1 & ND7EVR & UPG-CGK \\
\hline 38 & Shabry & GA & 1 & NEE4US & UPG-CGK \\
\hline 39 & Devi anjelita & GA & 1 & OX9M7Y & UPG-CGK \\
\hline 40 & Debi elsa T & GA & 1 & NDVSW2 & UPG-CGK \\
\hline 41 & Topik hidayat & GA & 1 & NESXV4 & CGK-BKS \\
\hline 42 & M Daud & JT & 2 & HQJOMV & BKS-MJU \\
\hline 43 & M Daud & JT & 2 & PFLWKN & MJU-BKS \\
\hline 44 & Surya utami ningsi & GA & 1 & QD9OX8 & BKS-CGK \\
\hline 45 & RA Syafitri pratiwi & GA & 1 & PE8536 & BKS-PLM \\
\hline 46 & Surya utami ningsi & GA & 2 & QDBGYT & SRG-BKS \\
\hline 47 & Agus salim & GA & 1 & NDUWP5 & UPG-CGK \\
\hline 48 & Rudi hartono & GA & 1 & NDVNZN & UPG-CGK \\
\hline 49 & Ade tri anggreini & GA & 1 & SY53WI & BKS-CGK \\
\hline 50 & Devie purnama ningsi & GA & 1 & SY53WI & BKS-CGK \\
\hline 51 & Dufferez putra D & GA & 1 & SY53WI & BKS-CGK \\
\hline 52 & Aryantito akbar & GA & 1 & SY53WI & BKS-CGK \\
\hline 53 & Azzahra salsabila & GA & 1 & SYD5OY & BKS-CGK \\
\hline 54 & Nobela sari & GA & 1 & SYD5OY & BKS-CGK \\
\hline 55 & Devi anjelita & GA & 1 & SYD5OY & BKS-CGK \\
\hline 56 & Yuike desri yanti & GA & 1 & SYD5OY & BKS-CGK \\
\hline 57 & Selvianita pramesti & GA & 1 & SYD5OY & BKS-CGK \\
\hline 58 & Annisa rahma J & GA & 1 & SZ38X6 & BKS-CGK \\
\hline 59 & Salju qurrata $\mathrm{A}$ & GA & 1 & SZ38X6 & BKS-CGK \\
\hline 60 & Emagina rahmanita & GA & 1 & SZ38X6 & BKS-CGK \\
\hline 61 & Tiara hunnun $\mathrm{E}$ & GA & 1 & SZ38X6 & BKS-CGK \\
\hline 62 & Risky pritasari & GA & 1 & SZ38X6 & BKS-CGK \\
\hline 63 & Debi elsa $\mathrm{T}$ & GA & 1 & SZG8VZ & BKS-CGK \\
\hline 64 & Andika & GA & 1 & SZG8VZ & BKS-CGK \\
\hline 65 & Agus salim & GA & 1 & SZG8VZ & BKS-CGK \\
\hline 66 & Ari nurdiana & GA & 1 & SZG8VZ & BKS-CGK \\
\hline 67 & Rudi hartono & GA & 1 & SZG8VZ & BKS-CGK \\
\hline 68 & M Daud & GA & 1 & SZRZ4C & BKS-CGK \\
\hline
\end{tabular}


Jurnal Keilmuan Teknik: Aplikasi, Perencanaan, Rancang Bangun, Sistem, Simulasi, \& Rekaya:

\begin{tabular}{|c|c|c|c|c|c|}
\hline 69 & Ibrahim & GA & 1 & SZRZ4C & BKS-CGK \\
\hline 70 & Shabry & GA & 1 & SZRZ4C & BKS-CGK \\
\hline 71 & Eva nopianti & GA & 1 & SZRZ4C & BKS-CGK \\
\hline 72 & Erika kurniat & GA & 1 & SZRZ4C & BKS-CGK \\
\hline 73 & Feni putri anjani & GA & 1 & SYIE3O & BKS-CGK \\
\hline 74 & Ardi Muhaimin & GA & 1 & SYIE3O & BKS-CGK \\
\hline 75 & Mulya sarti apriani & GA & 1 & SYIE3O & BKS-CGK \\
\hline 76 & Nur aulia siswisiarni & GA & 1 & SYIE3O & BKS-CGK \\
\hline 77 & Reko muhardi & GA & 1 & SYIE3O & BKS-CGK \\
\hline 78 & Chintya Dewi & GA & 2 & K5JO7P & CGK-MJU \\
\hline 79 & Azzahra salsabila & GA & 2 & K7DN3Q & CGK-MJU \\
\hline 80 & Feni putri anjani & GA & 2 & K7WKEA & CGK-MJU \\
\hline 81 & Ardi Muhaimin & GA & 2 & K8M7UL & CGK-MJU \\
\hline 82 & Mulya sarti apriani & GA & 2 & K8BECV & CGK-MJU \\
\hline 83 & Nur aulia siswisiarni & GA & 2 & K8SHXO & CGK-MJU \\
\hline 84 & Tiara hunnun $\mathrm{E}$ & GA & 2 & $\mathrm{~K} 9 \mathrm{C} 7 \mathrm{KO}$ & CGK-MJU \\
\hline 85 & Salju qurrata A & GA & 2 & K8YMQM & CGK-MJU \\
\hline 86 & Annisa rahma J & GA & 2 & KAOM7H & CGK-MJU \\
\hline 87 & Emagina rahmanita & GA & 2 & KB9ZY9 & CGK-MJU \\
\hline 88 & Risky pritasari & GA & 2 & KBJJAY & CGK-MJU \\
\hline 89 & Andika & GA & 2 & KBNYHN & CGK-MJU \\
\hline 90 & Ari nurdiana & GA & 2 & KBNP5X & CGK-MJU \\
\hline 91 & Debi elsa $\mathrm{T}$ & GA & 2 & KBV3PW & CGK-MJU \\
\hline 92 & Agus salim & GA & 2 & KCE28D & CGK-MJU \\
\hline 93 & Rudi hartono & GA & 2 & KCN52S & CGK-MJU \\
\hline 94 & Shabry & GA & 2 & KCMTSH & CGK-MJU \\
\hline 95 & Eva nopianti & GA & 2 & KDETJ5 & CGK-MJU \\
\hline 96 & Erika kurniat & GA & 2 & KCXHJ8 & CGK-MJU \\
\hline 97 & Selvianita pramesti & GA & 2 & K5UNXX & CGK-MJU \\
\hline 98 & Dufferez putra D & GA & 2 & K4BTUA & CGK-MJU \\
\hline 99 & Aryantito akbar & GA & 2 & K3BI7N & CGK-MJU \\
\hline 100 & Ade tri anggreini & GA & 2 & K3P3PF & CGK-MJU \\
\hline 101 & Devi anjelita & GA & 2 & K6RZHA & CGK-MJU \\
\hline 102 & Nobela sari & GA & 2 & K5YOH5 & CGK-MJU \\
\hline 103 & Yuike desri yanti & GA & 2 & K6O8IH & CGK-MJU \\
\hline 104 & Devie purnama ningsi & GA & 2 & K3STP4 & CGK-MJU \\
\hline 105 & Risky pritasari & JT & 1 & NCVJOO & MJU-UPG \\
\hline 106 & Yuike desri yanti & JT & 1 & MTEBIS & MJU-UPG \\
\hline 107 & Feni putri anjani & JT & 1 & CSBTCW & MJU-UPG \\
\hline 108 & Rudi hartono & JT & 1 & AMVGHO & MJU-UPG \\
\hline 109 & Ibrahim & JT & 1 & LCSDKS & MJU-UPG \\
\hline 110 & Ade tri anggreini & JT & 1 & HDHSFN & MJU-UPG \\
\hline 111 & Devie purnama ningsi & JT & 1 & & MJU-UPG \\
\hline 112 & Ari nurdiana & JT & 1 & PVRLIP & MJU-UPG \\
\hline 113 & Chintya Dewi & JT & 1 & WTYVUB & MJU-UPG \\
\hline 114 & Reko muhardi & JT & 1 & WLGMXE & MJU-UPG \\
\hline 115 & Nur aulia siswisiarni & JT & 1 & VUPFUL & MJU-UPG \\
\hline 116 & Emagina rahmanita & JT & 1 & PTVPDB & MJU-UPG \\
\hline 117 & Shabry & JT & 1 & MERVXG & MJU-UPG \\
\hline 118 & Azzahra salsabila & JT & 1 & LEVZRF & MJU-UPG \\
\hline 119 & Nobela sari & JT & 1 & LERDBL & MJU-UPG \\
\hline 120 & Agus salim & JT & 1 & LEFMYG & MJU-UPG \\
\hline 121 & Debi elsa T & JT & 1 & LECMMB & MJU-UPG \\
\hline 122 & Selvianita pramesti & JT & 1 & HFZPWD & MJU-UPG \\
\hline
\end{tabular}




\section{EATOT RACA}

Jurnal Keilmuan Teknik: Aplikasi, Perencanaan, Rancang Bangun, Sistem, Simulasi, \& Rekaya:

\begin{tabular}{|c|c|c|c|c|c|}
\hline 123 & Devi anjelita & JT & 1 & CTFLYU & MJU-UPG \\
\hline 124 & Mulya sarti apriani & JT & 1 & AKBHOD & MJU-UPG \\
\hline 125 & Aryantito akbar & JT & 1 & GFJLMG & MJU-UPG \\
\hline 126 & Dufferez putra D & JT & 1 & GFNZHY & MJU-UPG \\
\hline 127 & Erika kurniat & JT & 1 & GGUHTR & MJU-UPG \\
\hline 128 & Salju qurrata A & JT & 1 & GHSFAB & MJU-UPG \\
\hline 129 & Annisa rahma $\mathrm{J}$ & JT & 1 & PTUVGN & MJU-UPG \\
\hline 130 & Tiara hunnun E & JT & 1 & PTZMXC & MJU-UPG \\
\hline 131 & Ardi Muhaimin & JT & 1 & QXPGMC & MJU-UPG \\
\hline 132 & Eva nopianti & JT & 1 & QXBPTL & MJU-UPG \\
\hline 133 & Andika & JT & 1 & RCGGVB & MJU-UPG \\
\hline 134 & Rio marel & GA & 1 & JOFESO & PLM-BKS \\
\hline 135 & Rini meyla & GA & 1 & JSA5ZC & PLM-BKS \\
\hline 136 & Bambang sahono & QG & 1 & QESEQN & CGK-BKS \\
\hline 137 & Dika jaya afriani & GA & 1 & KSGTUV & PLM-DJB \\
\hline 138 & Maulya elsyahnty & GA & 1 & KSGTUV & PLM-DJB \\
\hline 139 & Nita Afriana & GA & 2 & KTV62K & KNO-BKS \\
\hline 140 & Nita Afriana & GA & 2 & HZPLIZ & BKS-KNO \\
\hline 141 & Bimo raharjo & JT & 1 & FZKFEEP & CGK-BKS \\
\hline 142 & Misebrata & JT & 1 & NYWDKR & BKS-CGK \\
\hline 143 & Topik hidayat & JT & 3 & AYLVLM & BKS-CGK \\
\hline 144 & Halimah & JT & 2 & YVVWEB & BKS-CGK \\
\hline 145 & Tunsia aini & $\mathrm{JT}$ & 1 & YTAPBS & CGK-BKS \\
\hline 146 & Heri listri ningsi & JT & 2 & ODSFZF & CGK-BKS \\
\hline 147 & Nelvi erizon & JT & 1 & FOINAR & BKS-CGK \\
\hline 148 & Repa terisnawati & JT & 1 & VTHHKV & CGK-BKS \\
\hline 149 & astriani & JT & 1 & LHFDBM & HLP-BKS \\
\hline 150 & astriani & JT & 1 & MZDDJH & BKS-CGK \\
\hline 151 & Joni ardi & JT & 2 & GEVADT & BKS-CGK \\
\hline 152 & Wahyu biantara & SJ & 2 & YBLYAT & BKS-JOG \\
\hline 153 & Repa terisnawati & GA & 1 & KUEDNW & BKS-CGK \\
\hline 154 & Bimo raharjo & JT & 1 & SOTJIP & BKS-CGK \\
\hline
\end{tabular}

Dari 154 sampel pada PT bulang didapat nilai konsistensi tabel diatas didapat dari matriks baris sehingga nilai dari perhitungan metode akan menampilkan nilai CR dan nilai konsistensi rata $\mathrm{CR} / \mathrm{Cl} 0,78$ seperti gambar dibawah ini dengan tingkat kepuasan konsumen dengan nilai rata-rata 0,75 .

\begin{tabular}{|c|c|c|c|}
\hline 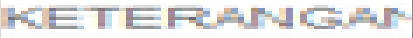 & DLITIIII & FIIDITIDID & $1-1= \pm=1$ \\
\hline$=5$ & $D_{-}= \pm$ & $L_{1}=0$ & $U_{m}=\underline{L}$ \\
\hline E & $11=2=$ & $D_{n}= \pm$ & DEED \\
\hline TE & ${ }_{1}=\mathrm{y}=$ & 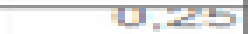 & DEDI \\
\hline$\equiv$ & $I_{-}= \pm \equiv$ & $D=-2$ & $M= \pm 10$ \\
\hline
\end{tabular}
Wiat CF adalah : -D, $7 \mathrm{~B}$ Nilai 1tomsitemsi 


\section{EATOT KAGA JOURNAL}

Jurnal Keilmuan Teknik: Aplikasi, Perencanaan, Rancang Bangun, Sistem, Simulasi, \& Rekaya:

Analisa Kecendrungan Masyarakat Terhadap Transportasi Udara Menggunakan Metode AHP Pada PT.Bulang Persada Tour dan Travel Kota Bengkulu.

\begin{tabular}{|c|c|c|c|c|c|c|c|c|}
\hline no & ID & MASKAPAI & Pelayanan & Sefty & Ekonomi & Wa ktu & NILAI & KETERANGAN \\
\hline \begin{tabular}{|l|}
1 \\
2 \\
3 \\
4 \\
5 \\
6 \\
7 \\
8 \\
9 \\
10 \\
11 \\
12 \\
13 \\
14 \\
15 \\
16 \\
17 \\
18 \\
19 \\
20 \\
21
\end{tabular} & $\begin{array}{l}J T \\
J T \\
J T \\
J T \\
J T \\
J T \\
J T \\
J T \\
J T \\
G A \\
G A \\
G A \\
G A \\
G A \\
G A \\
G A \\
\text { GA } \\
J T \\
S J \\
\text { SA } \\
J T\end{array}$ & 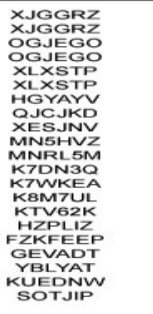 & $\begin{array}{l}77 \\
75 \\
76 \\
78 \\
80 \\
77 \\
78 \\
76 \\
75 \\
78 \\
79 \\
80 \\
78 \\
77 \\
70 \\
70 \\
72 \\
75 \\
76 \\
77 \\
80\end{array}$ & $\begin{array}{l}80 \\
76 \\
75 \\
74 \\
75 \\
75 \\
75 \\
78 \\
76 \\
78 \\
76 \\
77 \\
78 \\
75 \\
75 \\
75 \\
80 \\
72 \\
72 \\
74 \\
72\end{array}$ & $\begin{array}{l}82 \\
76 \\
75 \\
75 \\
75 \\
76 \\
74 \\
74 \\
74 \\
74 \\
74 \\
75 \\
76 \\
75 \\
75 \\
75 \\
76 \\
76 \\
75 \\
75 \\
75\end{array}$ & $\begin{array}{l}78 \\
78 \\
75 \\
70 \\
72 \\
72 \\
73 \\
73 \\
70 \\
72 \\
72 \\
72 \\
73 \\
73 \\
70 \\
72 \\
72 \\
73 \\
73 \\
70 \\
72 \\
72\end{array}$ & $\begin{array}{l}0.78 \\
0.75 \\
0.75 \\
0.75 \\
0.75 \\
0.75 \\
0.75 \\
0.75 \\
0.75 \\
0.75 \\
0.75 \\
0.75 \\
0.75 \\
0.75 \\
0.75 \\
0.75 \\
0.75 \\
0.75 \\
0.75 \\
0.75 \\
0.75\end{array}$ & $\begin{array}{l}\text { Laik } \\
\text { Laik } \\
\text { Laik } \\
\text { Laik } \\
\text { Laik } \\
\text { Laik } \\
\text { Laik } \\
\text { Laik } \\
\text { Laik } \\
\text { Laik } \\
\text { Laik } \\
\text { Laik } \\
\text { Laik } \\
\text { Laik } \\
\text { Laik } \\
\text { Laik } \\
\text { Laik } \\
\text { Laik } \\
\text { Laik } \\
\text { Laik } \\
\text { Laik } \\
\text { Laik }\end{array}$ \\
\hline
\end{tabular}

Memperoleh nilai selisih hasil normallisasi yang bernilai 0 , artinya proses iterasi tidak perlu lagi dilanjutkan. Karena proses iterasi berhenti pada iterasi 4, maka nilai pembobotan yang digunakan adalah nilai normalisasi hasil iterasi ke-4, sehingga, sekarang tiap-tiap elemen penyusun kriteria dapat di susun sebagai berikut:

1. Pelayanan rata-rata kepuasan masyarakat 77

2. Sefty rata-rata kepuasan masyarakat 80

3. Ekonomi rata-rata kepuasan masyarakat 82

4. Waktu rata-rata kepuasan masyarakat 78

5. Kenyamanan rata-rata kepuasan masyarakat 78

Terhadap pelayanan City Link dengan jadwal penerbangan yang nyaman tidak mengalami keterlambatan dengan akurasi CR 0.78 dengan nilai konsisten -0.86 dengan Penerbangan JT Maskapai XJGGRZ.

\section{Hasil Pengujian}

\section{Pengetesan Kotak Hitam (Black Boxt Test)}

Pengetesan ini dilakuan oleh pembimbing dan pegawai PT.Bulang. Pengetesan dilakukan dengan cara menjalankan program yaitu dengan memasukkan data-data yang berhubungan dengan Sistem Informasi. Berdasarkan uji coba Aplikasi pengolahan data agenda pada dinas Pemadam kebakaran kabupaten selumaproses penginputan maupun pemasukan data dan output dapat berjalan dengan baik.

Uji kelayakan sistem menggunakan angket yang diberikan kepada sampel yang telah ditentukan. Kategori penilaian dibagi menjadi 5 (lima) aspek, yaitu penilaian terhadap tampilan, kemudahan pengguna, kinerja sistem, keamanan dan ketelitian dan isi dari sistem informasi.

\section{Tabel 4.1. Hasil Pengujian Sistem}

\begin{tabular}{|c|c|c|c|}
\hline No. & Skenario Pengujian & Gambar & Kesimpulan \\
\hline 1 & $\begin{array}{l}\text { Menggosongkan Username dan } \\
\text { Password, Lalu langsung klik tombol } \\
\text { Login Test Case: }\end{array}$ & $\begin{array}{l}\text { Sistem akan menolak akses } \\
\text { login dan menampilkan } \\
\text { pesan "maaf anda belum } \\
\text { memasukan username dan } \\
\text { password. }\end{array}$ & Valid \\
\hline
\end{tabular}




\begin{tabular}{|c|c|c|c|}
\hline 2 & $\begin{array}{l}\text { Tampilan Program Setelah masuk ke } \\
\text { menu Login dan Username benar } \\
\text { password benar. }\end{array}$ & $\begin{array}{l}\text { Sistem akan menerimadan } \\
\text { masuk ke menu utama. }\end{array}$ & Valid \\
\hline 3 & $\begin{array}{l}\text { Tampilan Menu input Pesawat } \\
\text { apabila mengklik form input pesawat } \\
\text { maka tampilan seperti gambar } \\
\text { dibawah ini. }\end{array}$ & $\begin{array}{l}\text { Apabila memasukan kode } \\
\text { yang sama maka tampilan } \\
\text { akan memberitahukan } \\
\text { duplicate atau Bug. }\end{array}$ & Valid \\
\hline 4 & $\begin{array}{l}\text { Tampilan Kreteria adalah tampilan } \\
\text { dimana akan memasukan menu } \\
\text { kreteria ketika kita menginputkan } \\
\text { tambahn simpan, hapus dan koreksi } \\
\text { maka tampilan seperti disamping. }\end{array}$ & $\begin{array}{l}\text { Apabila memasukan kode } \\
\text { yang sama maka tampilan } \\
\text { akan memberitahukan } \\
\text { duplicate atau Bug. } \\
\begin{array}{|l}\text { Hapus } \\
\text { rakin hapus record? }\end{array}\end{array}$ & Valid \\
\hline 5 & $\begin{array}{l}\text { Tampilan Perbandingan dimana } \\
\text { memasukan angka didalam menu } \\
\text { diatas. }\end{array}$ & $\begin{array}{l}\text { Apabila memasukan kode } \\
\text { yang sama maka tampilan } \\
\text { akan memberitahukan } \\
\text { duplicate atau Bug. }\end{array}$ & Valid \\
\hline 6 & Tampilan matrik & $\begin{array}{l}\text { Apabila memasukan kode } \\
\text { yang sama maka tampilan } \\
\text { akan memberitahukan } \\
\text { duplicate atau Bug. }\end{array}$ & Valid \\
\hline 77 & 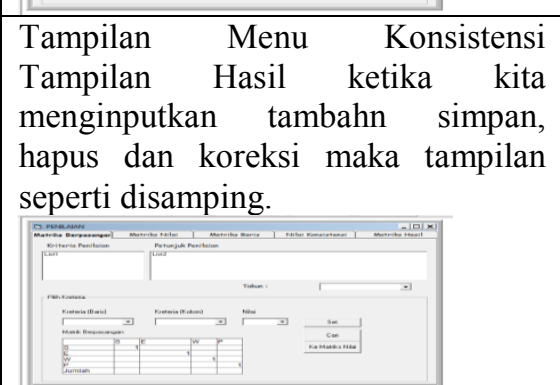 & $\begin{array}{l}\text { Apabila memasukan kode } \\
\text { yang sama maka tampilan } \\
\text { akan memberitahukan } \\
\text { duplicate atau Bug. }\end{array}$ & Valid \\
\hline 8 & $\begin{array}{l}\text { Tampilan Hasil ketika kita } \\
\text { menginputkan tambahn simpan, } \\
\text { hapus dan koreksi maka tampilan }\end{array}$ & $\begin{array}{l}\text { Apabila memasukan kode } \\
\text { yang } \\
\text { akan }\end{array}$ & Valid \\
\hline
\end{tabular}




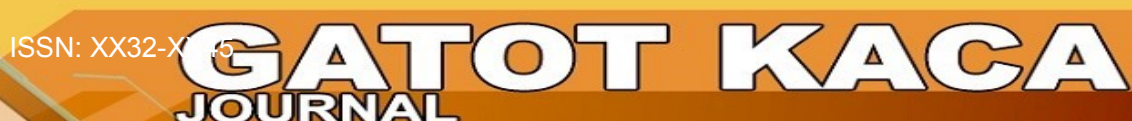

\begin{tabular}{|l|l|l|l|}
\hline & $\begin{array}{l}\text { seperti disamping. } \\
\text { Tampilan Laporan apabila mengklik }\end{array}$ & duplicate atau Bug. & \\
\hline 9 & \begin{tabular}{l} 
tombol output. \\
\hline I
\end{tabular} & & Valid \\
\hline
\end{tabular}

\section{KESIMPULAN DAN SARAN}

\section{Kesimpulan}

a. Sistem Aplikasi kecendrungan masyarakat terhadap transportasi udara menggunakan Metode AHP Menggunakan Visual Basic 6.0.dalam melakukan penyebaran akses informasi dan komunikasi belum secara khusus menggunakan aplikasi untuk memudahkannya. Sedangkan informasi yang disampaikan masih menggunakan dan selebaran atau kotak saran pada bandara fatmawati sehingga informasi yang ditampung tidak akurat.

b. Sistem Aplikasi kecendrungan masyarakat terhadap transportasi udara menggunakan Metode AHP Menggunakan Visual Basic dapat menjadi masukan kepada pihak maskapai sehingga menjadi bandara bertaraf internasional.

\section{Saran}

Sistem Aplikasi kecendrungan masyarakat terhadap transportasi udara menggunakan Metode AHP Menggunakan Visual Basic maka dirasa perlu tenaga yang memang betul-betul menguasai komputer secara umum, dan menguasai secara khusus pemrograman Visual basic 6.0 agar sistem informasi yang telah dibuat dapat berjalan secara optimal.

\section{DAFTAR PUSTAKA}

Alam, Agus, 2005.Pemrograman Databas Borland Delphi dalam SQL Server 7.0 \& 2005. Penerbit :PT Elex Media Komputindo. Jakarta. $140 \mathrm{Hal}$

Hartono, 2000. Sistem Informasi. Penerbit : Andi Offset. Yogyakarta. $820 \mathrm{Hal}$

Imam, Kamarul, 2008.Manajemen Persediaan. diakses 15 April 2008. $98 \mathrm{Hal}$ (http://www.ppimk.or.id/produk/inventory/index.php?id=2)

Jogiyanto, H, 2002. Pengenalan Komputer. Penerbit: Andi Offset. Yogyakarta. $896 \mathrm{Hal}$ Jogiyanto, H, 2001. Sistem Informasi. Penerbit: Andi Offset. Bandung. $635 \mathrm{Hal}$

Kadir, Abdul, 2003. Pengenalan Sistem Informasi. Penerbit : Andi Offset. Yogyakarta. $278 \mathrm{Hal}$

Kristanto Harianto, Ir, 2004.Konsep dan Perancangan DataBase.Penerbit : Andi Offset. Yogyakarta. $154 \mathrm{Hal}$

Moekijat, Drs, 2003. Pengantar Sistem Informasi dan Manajemen.Penerbit : PT. Remaja Rosdakarya. Bandung. $170 \mathrm{Hal}$

Murdick \& Ross, dalam Fatta 2007, 2004.Riset Operasi. Penerbit : Fakultas Ekonomi Universitas Indonesia. Jakarta. $347 \mathrm{Hal}$

Stair, 2003.Riset Operasi Untuk Pengambilan Keputusan. Penerbit : Universitas Indonesia ( UI__Press). Jakarta. $407 \mathrm{Ha}$ 


\section{बATO

Ulum, Miftahul, 2005. Mahir Merakit Komputer. Penerbit : Trubus agrisara. Surabaya. $178 \mathrm{Hal}$

Waluya, 2001.Basis Data.Penerbit : Andi Offset. Yogyakarta. 86 Hal

Yuwono, Trisno, 2004. Kamus Besar Bahasa Indonesia.Penerbit : Arkola, Surabaya. $762 \mathrm{Hal}$. 